\title{
Effects of Coptis extract combined with chemotherapeutic agents on ROS production, multidrug resistance, and cell growth in A549 human lung cancer cells
}

Chengwei $\mathrm{He}^{1,2,3}$, Rong Rong ${ }^{1,4}$, Jing Liu' ${ }^{1}$ Jianbo Wan ${ }^{2,3}$, Keyuan Zhou ${ }^{5}$ and Jing X Kang ${ }^{1 *}$

\begin{abstract}
Background: Non-small cell lung cancer is associated with high expression of multidrug resistance (MDR) proteins and low production of reactive oxygen species (ROS). Coptis extract (COP), a Chinese medicinal herb, and its major constituent, berberine (BER), have anticancer properties. This study aims to investigate the effects of COP and BER combined with chemotherapeutic agents, including fluorouracil (5-FU), camptothecin (CPT), and paclitaxel (TAX), on cell proliferation, ROS production, and MDR in A549 human non-small cell lung cancer cells.

Methods: A549 cells were treated with different doses of COP and BER, combined with 5-FU, CPT, and TAX. Cell viability was measured by an XTT (2,3-bis-(2-methoxy-4- nitro-5-sulfophenyl)-2 H-tetrazolium-5-carboxanilide) assay. Intracellular ROS levels were determined by measuring the oxidative conversion of cell permeable $2^{\prime}, 7^{\prime}$ -

dichlorofluorescein diacetate to fluorescent dichlorofluorescein. MDR of A549 cells was assessed by rhodamine 123 retention assay.
\end{abstract}

Results: Both COP and BER significantly inhibited A549 cell growth in a dose-dependent manner. Combinations of COP or BER with chemotherapeutic agents (5-FU, CPT, and TAX) exhibited a stronger inhibitory effect on A549 cell growth. In addition, COP and BER increased ROS production and reduced MDR in A549 cells.

Conclusion: As potential adjuvants to chemotherapy for non-small cell lung cancer, COP and BER increase ROS production, reduce MDR, and enhance the inhibitory effects of chemotherapeutic agents on A549 cell growth.

\section{Background}

The herb Coptis (COP) is used to treat "damp heat" syndrome in Chinese medicine [1]. Its major constituent is berberine (BER), an isoquinoline alkaloid [2]. The anticancer effects of COP and BER on both hematological and nonhematological cancers have been well documented [3]. Since 2000, experimental studies have confirmed the cytotoxicity of BER in various cancer cell lines, including YES (esophageal carcinoma) [4], HK1 (nasopharyngeal carcinoma) [5], HeLa (cervical carcinoma) [6], HepG2 (hepatocellular carcinoma)

\footnotetext{
*Correspondence: kang.jing@mgh.harvard.edu

'Department of Medicine, Massachusetts General Hospital and Harvard

Medical School, Charlestown, Boston, MA 02129, USA

Full list of author information is available at the end of the article
}

[7]. Our previous studies $[9,10]$ have also shown that COP inhibits the growth of breast cancer cells.

Non-small cell lung cancer (NSCLC) accounts for approximately $85 \%$ of lung cancers, and only responds to $15 \%-25 \%$ single agents and $25 \%-40 \%$ combined chemotherapy [11]. NSCLC is typically resistant to apoptosis induced by standard chemotherapy, which causes excessive levels of reactive oxygen species (ROS), leading to impaired intracellular ionic homeostasis by damaging cellular macromolecules and inducing apoptosis [12]. Mitochondrial ROS production is crucial to NSCLC apoptosis induced anticancer agents [13]. In addition to ROS, multidrug-resistance (MDR) proteins are intrinsically expressed and functionally active in NSCLC cells [14]. Several adjuvants to chemotherapy for NSCLC are being tested, with promising results, including the antagonists of EGFR and COX-2 [15-17].

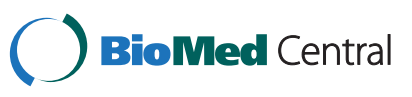

(C) 2012 He et al.; licensee BioMed Central Ltd. This is an Open Access article distributed under the terms of the Creative Commons Attribution License (http://creativecommons.org/licenses/by/2.0), which permits unrestricted use, distribution, and reproduction in any medium, provided the original work is properly cited. 
This study aims to investigate the effects of COP and BER on ROS production and MDR, and the effects of combinations of COP or BER with chemotherapeutic agents, including fluorouracil (5-FU), camptothecin (CPT), and paclitaxel (TAX) on A549 human cancer cells, which are derived from NSCLC [18].

\section{Methods}

Materials

A powder form of COP extract was made from Coptis japonica (Mayway Corporation, Oakland, CA, USA) by boiling the plant in water and spray drying. A solution of COP was prepared as previously described [10]. BER, 5-FU, CPT, and TAX were purchased from SigmaAldrich (USA). BER, 5-FU, and CPT were dissolved in dimethylsulfoxide (DMSO) (Sigma-Aldrich, USA), and TAX was dissolved in $100 \%$ ethanol (Fisher Scientific, USA). The final concentrations of DMSO and ethanol in the medium were less than $0.1 \%$.

\section{Cell culture}

The A549 cell line (ATCC CCL-185) was purchased from ATCC (Manassas, VA, USA). The cells were cultured in Dulbecco's Modified Eagle Medium (DMEM) (Invitrogen, Carlsbad, CA, USA) supplemented with 100 $\mathrm{U} / \mathrm{mL}$ penicillin, $100 \mathrm{~g} / \mathrm{mL}$ streptomycin, and $10 \%$ inactivated fetal calf serum (FBS, HyClone, South Logan, UT, USA). The cells were incubated at $37^{\circ} \mathrm{C}$ under a humidified atmosphere of $95 \%$ air and $5 \% \mathrm{CO}_{2}$. Cells were subcultured twice weekly.

\section{Cell viability assay}

A549 cells were seeded in 96 -well plastic plates $\left(3 \times 10^{3}\right.$ cells/well) and incubated at $37^{\circ} \mathrm{C}$ in complete medium for $16 \mathrm{~h}$ before the drug treatment for $72 \mathrm{~h}$. Cell viability was assessed by the XTT (2,3-bis-(2-methoxy-4- nitro-5sulfophenyl)-2 H-tetrazolium-5-carboxanilide) assay (Invitrogen, Carlsbad, CA, USA) . The spectrophotometric absorbance of the samples was measured using a microplate reader $\left(\right.$ VICTOR $^{3} \mathrm{~V}^{\mathrm{m}} 1420$ Multilabel Counter, PerkinElmer, Waltham, MA, USA) at $490 \mathrm{~nm}$ with a reference wavelength of $690 \mathrm{~nm}$. Each measurement was performed in triplicate and the data reported were mean values of at least 3 experiments. The inhibitory effect was calculated according to the following equation:

$$
\begin{aligned}
\text { Inhibition }(\%)= & {[1-(\mathrm{A} 490 \text { of treated wells } / \text { A490 of control wells })] } \\
& \times 100 .
\end{aligned}
$$

\section{Measurement of reactive oxygen species}

Intracellular ROS levels were determined by measuring the oxidative conversion of cell permeable 2', 7' dichlorofluorescein diacetate (DCFH-DA; Sigma-Aldrich, USA) to fluorescent dichlorofluorescein (DCF) [13]. Cells were plated in 24-well culture plates $\left(2 \times 10^{5}\right.$ cells/well $)$ and incubated with drugs for $24 \mathrm{~h}$. The cells were then washed with D-Hank's solution (Invitrogen, USA) and incubated with $10 \mu \mathrm{M}$ DCFH-DA in phenol-red-free MEM medium (Invitrogen, USA) at $37^{\circ} \mathrm{C}$ for $15 \mathrm{~min}$. DCF fluorescence distribution was measured in a microplate reader (PerkinElmer, Waltham, MA, USA) at an excitation wavelength of $488 \mathrm{~nm}$ and emission wavelength of $535 \mathrm{~nm}$. The fluorescence intensity was normalized according to the number of cells.

\section{Rhodamine 123 retention assay}

Rhodamine 123 retention was measured to evaluate the multidrug resistance (MDR) of cancer cells [19,20]. Briefly, 24-well plates with $2 \times 10^{5}$ cells/well were treated with low or high doses of COP (low dose: $1.6 \mu \mathrm{g} /$ $\mathrm{mL}$, high dose: $6.4 \mu \mathrm{g} / \mathrm{mL}$ ) and BER (low dose: $0.5 \mu \mathrm{g} /$ $\mathrm{mL}$, high dose: $4 \mu \mathrm{g} / \mathrm{mL}$ ) for $24 \mathrm{~h}$. The cells were then incubated in phenol-red-free MEM containing $10 \mu \mathrm{g} / \mathrm{mL}$ rhodamine 123 (Sigma-Aldrich, USA) and 2\% FBS for $20 \mathrm{~min}$ at $37^{\circ} \mathrm{C}$. After incubation, the cell monolayers were washed 3 times with ice-cold phosphate buffered saline (PBS), trypsinized, and suspended in MEM medium containing 2\% FBS. The cell suspension was transferred to a 96-well plate and measured in a microplate reader (PerkinElmer,Waltham, MA, USA) at an excitation wavelength of $485 \mathrm{~nm}$ and emission wavelength of $535 \mathrm{~nm}$. The fluorescence intensity was normalized by the number of cells. All experiments were performed in quadruplicate.

\section{Statistical analysis}

The data were expressed as means \pm standard deviations (SD). A one-way ANOVA was performed to test the difference among groups of controls, individual agents, and combinations of agents using Graph Pad Prism 4 software (San Diego, CA, USA). NewmanKeuls tests were used for multiple comparisons. The software did not provide exact $P$ values for ANOVA; thus, no exact $P$ values are reported. The results with $P<0.05$ were considered statistically significant. Each experiment was repeated at least 3 times.

\section{Results}

\section{A549 cell growth}

The A549 cell line was treated with different doses of COP and BER and tested for cell viability with an XTT assay to examine the effects of COP and BER on cancer cell growth. As shown in Figure 1, treatment with COP at 6.4 to $51.2 \mu \mathrm{g} / \mathrm{mL}$ or BER at 2.0 to $16.0 \mu \mathrm{g} / \mathrm{mL}$ for 72 h significantly inhibited A549 cell growth. The maximum inhibition rates were $60 \%$ and $64 \%$ for COP and BER, respectively. A Pearson Correlation Test by Prism 4 was used to determine the correlation between the 


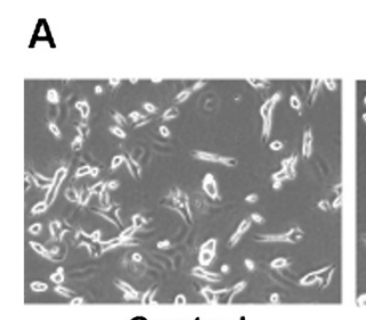

Control

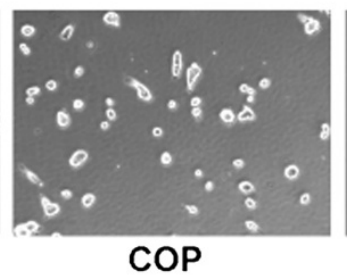

COP

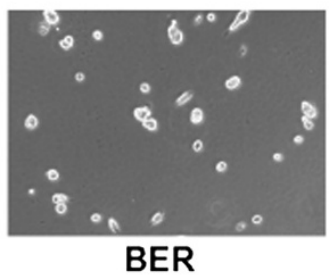

BER

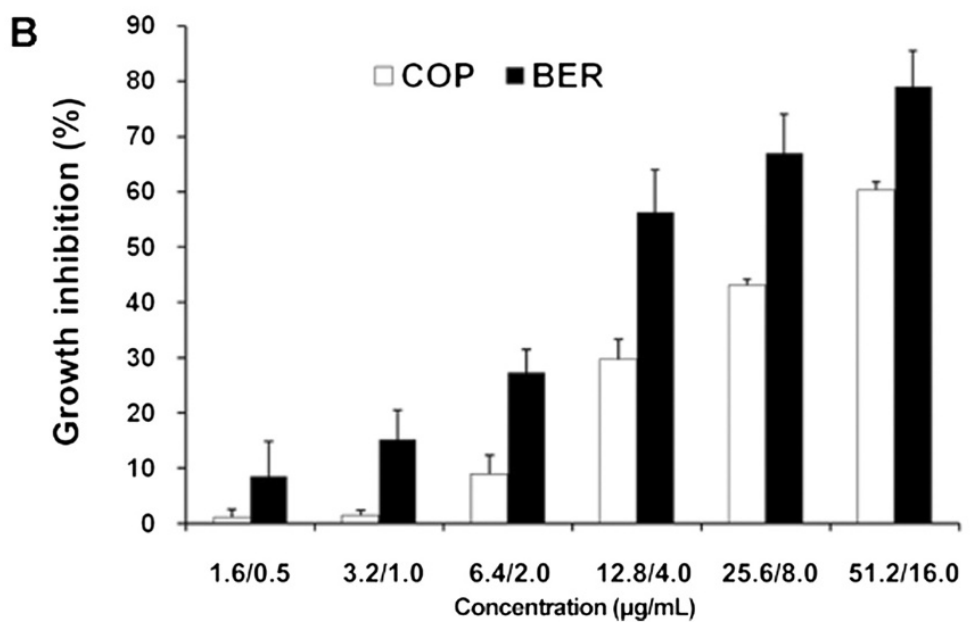

Figure 1 Effects of COP and BER on the growth of A549 cells. A. Morphological changes of A549 cells treated with $6.4 \mu \mathrm{g} / \mathrm{mL} \mathrm{COP}$ or $4.0 \mu \mathrm{g} /$ $\mathrm{mL}$ BER for $72 \mathrm{~h}$ under inverted phase contrast microscope $(200 \times)$. B. Treatment with COP and BER for $72 \mathrm{~h}$ inhibited A549 cell growth $(P<0.01)$ [Pearson Correlation Test, $P=0.0032$ for COP; $P=0.0178$ for BER] in a dose-dependent manner. Values are means \pm SD of 4 independent assays.

doses of COP or BER and the inhibitory effects on A549 cell growth. The results indicated that the growth inhibition was in a dose-dependent manner $[P=0.0032$ for COP; $P=0.0178$ for BER].

Low and high doses of COP or BER combined with 5FU, CPT, or TAX were used to treat A549 cells to investigate the inhibitory effects of COP and BER in combination with chemotherapeutic drugs on cancer cells. As shown in Figure 2, a combination of a low dose of $\mathrm{COP}$ and chemotherapeutic drugs had an inhibitory effect stronger than CPT or TAX alone on cancer cell growth $(P<0.001$ for both CPT and TAX), whereas high doses of COP enhanced the inhibitory effects of CPT, TAX, and 5FU on A549 cell growth $(P<0.001$ for CPT, TAX, and 5FU). In addition, the combination of a high dose of BER with chemotherapeutic drugs exhibited an inhibitory effect stronger than CPT, TAX, or 5FU alone on A549 cell growth. These findings suggest a potential use of COP and BER as adjuvant therapies for NSCLC.

\section{Production of reactive oxygen species in A549 cells}

The intracellular levels of ROS production were measured after treatment with low or high doses of COP and BER. As shown in Figure 3, low doses of COP and BER increased ROS production by approximately $50 \%$ $(P<0.05)$, relative to the control group, and ROS production in the cells incubated with high doses of COP and BER was nearly 3 times that of the control group $(P<0.01, \mathrm{n}=4)$.

Our results show that both COP and BER significantly increased ROS levels in A549 cells, in a dose-dependent manner, and enhanced the inhibitory effect of chemotherapeutic drugs on A549 cells. The present study agrees with previous findings that ROS production is increased in cancer cells [21], which sensitizes the cancer cells to drugs $[13,22]$ and to radiotherapy [23]. It has been reported [24] that BER enhances the anticancer effect of irradiation by increasing ROS production in human hepatoma cells.

\section{Inhibition of MDR in A549 cells}

Rhodamine 123 retention in A549 cells was tested to determine whether COP and BER affect MDR. As shown in Figure 4, both low and high doses of COP and BER enhanced dye retention by as much as $40 \%(P<0.05)$. Because elevated dye retention levels are inversely 


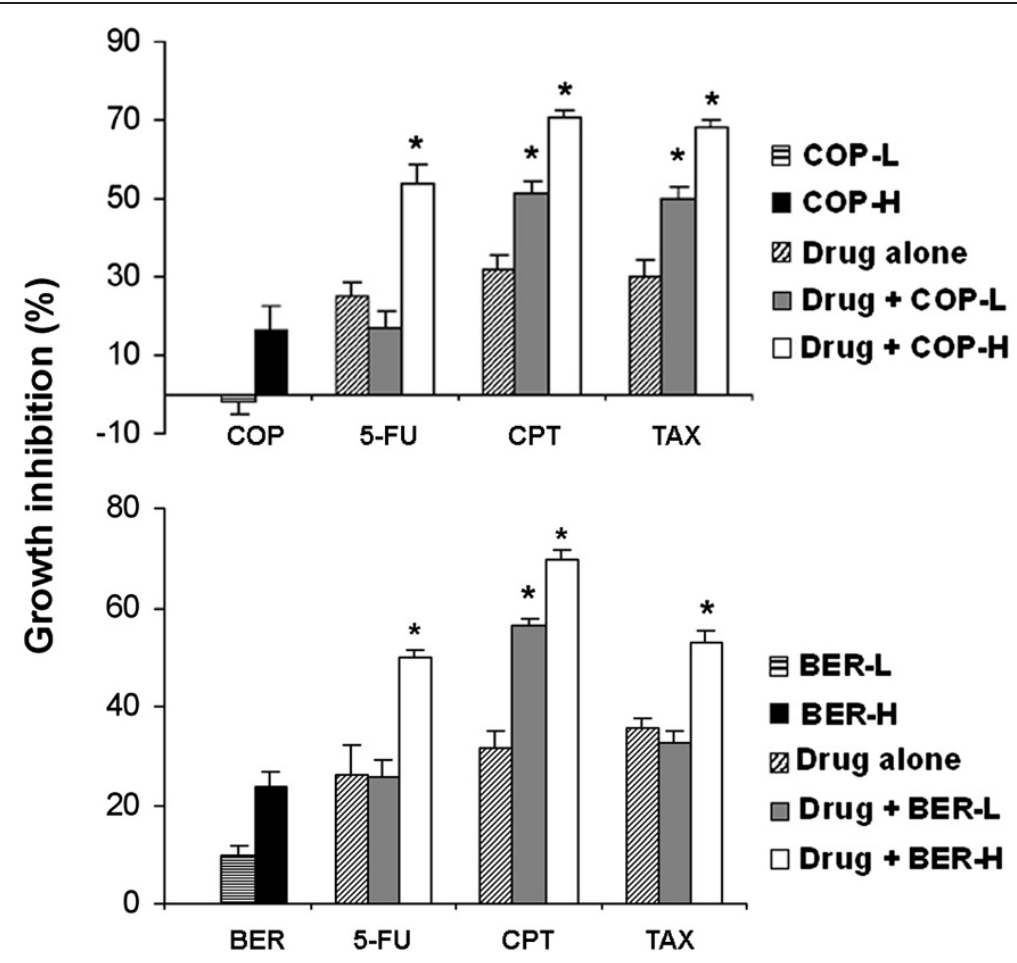

Figure 2 Growth inhibition by combined use of COP/BER and chemotherapeutic agents in A549 cells. Effects of COP or BER, combined with 5-fluorouracil (5-FU), camptothecin (CPT), or paclitaxel (TAX), on the growth of A549 cells. COP-L: $1.6 \mu \mathrm{g} / \mathrm{mL} ; \mathrm{COP}-\mathrm{H}: 6.4 \mu \mathrm{g} / \mathrm{mL} ; \mathrm{BER}-\mathrm{L}$ : $0.5 \mu \mathrm{g} / \mathrm{mL} ; \mathrm{BER}-\mathrm{H}: 4 \mu \mathrm{g} / \mathrm{mL}$. ${ }^{*} P<0.05$, compared to drugs alone. Values are means $\pm \mathrm{SD}$ of 4 independent assays.

related to MDR [20], this suggests that the inhibitory effects of COP and BER on A549 cells were enhanced due to the prolonged intracellular retention of the chemotherapeutic drugs.

\section{Discussion}

NSCLC is extremely difficult to treat because of its low therapeutic and long-term survival rates [11]. This study demonstrates that a combination of COP or its major constituent BER with chemotherapeutic drugs including
5-FU, CPT, and TAX exhibits a stronger inhibitory effect on the growth of A549 human lung cancer cells than any individual treatment. These findings suggest a potential use of COP and BER in the adjuvant treatment of NSCLC.

ROS levels are elevated in cells exposed to various stressors, including anticancer drugs, leading to apoptosis by stimulating pro-apoptotic signaling molecules (e.g., P53, MAPK, etc.) [25]. Some studies [13,22] have shown that increasing the production of ROS may sensitize cancer cells to drugs. Our results show that both COP and BER

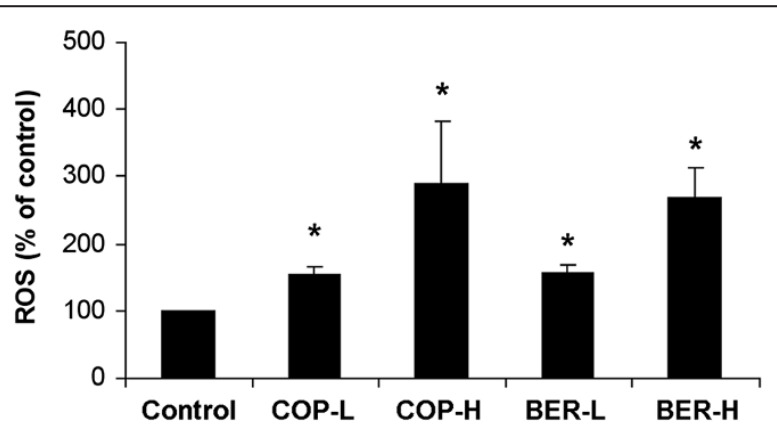

Figure 3 Effects of COP and BER on ROS production in A549 cells. Cells were treated with COP-L (1.6 $\mu \mathrm{g} / \mathrm{mL}), C O P-H(6.4 \mu \mathrm{g} / \mathrm{mL}), \mathrm{BER}-\mathrm{L}$ $(0.5 \mu \mathrm{g} / \mathrm{mL})$, or BER-H $(4 \mu \mathrm{g} / \mathrm{mL})$ for $24 \mathrm{~h}$ and harvested for ROS determination. ${ }^{*} P<0.05$ compared to control. Values are means \pm SD of 4 independent assays. 


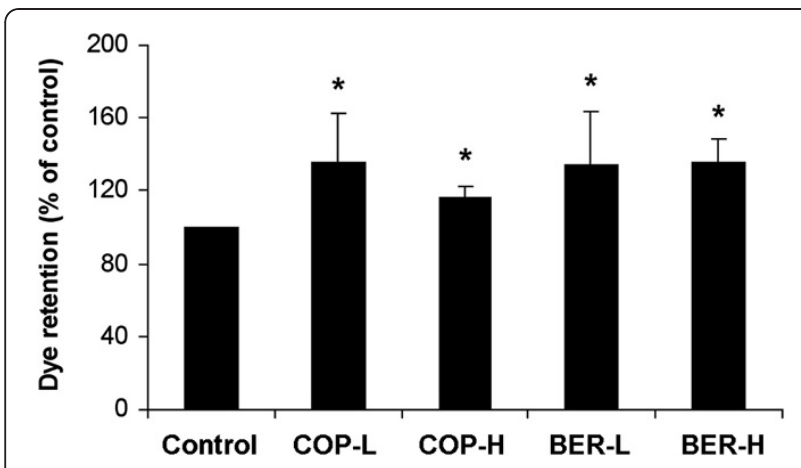

Figure 4 Effects of COP and BER on MDR in A549 cells. Cells were treated with COP-L $(1.6 \mu \mathrm{g} / \mathrm{mL}), C O P-H(6.4 \mu \mathrm{g} / \mathrm{mL})$, BER-L $(0.5 \mu \mathrm{g} / \mathrm{mL})$, or BER-H $(4 \mu \mathrm{g} / \mathrm{mL})$ for $24 \mathrm{~h}$ and harvested for dye retention determination. ${ }^{*} P<0.05$ compared to control. Values are means \pm SD of 4 independent assays.

significantly increase ROS levels in A549 cancer cells in a dose-dependent manner, which is consistent with the enhanced inhibitory effect of chemotherapeutic drugs combined with COP or BER on A549 cancer cells.

Multiple drug resistance (MDR) is still the major cause of cancer therapy failure. MDR involves the overexpression of membrane P-glycoprotein (Pgp) and a reduced ability to accumulate and retain therapeutic drugs because of the energy-dependent Pgp efflux pump. Almost all NSCLC display intrinsic MDR, generally limiting the chance of successful chemotherapy [23, 24]; this is a key reason why lung cancer is currently a leading cause of cancer death worldwide. Combined therapy with cytotoxic drugs and MDR modulators is a promising strategy for overcoming clinical MDR. Some traditional herbal medicines, such as Coptis, Poria, and Zizyphi fructushave been reported to reverse MDR [25]. Our results show that COP and BER at low and high doses significantly increase the retention of Rhodamine 123 dye, suggesting an inhibition of P-gp and/or MRP efflux activity in the A549 cancer cells. In turn, decreased MDR activity may contribute to the inhibitory effects of chemotherapeutic drugs in conjunction with COP and BER on A549 cancer cells. However, Lin et al. reported [26] that berberine up-regulated MDR transporter pgp-170 expression and reduced the response to paclitaxel in digestive track cancer cells. We assume that different types of cell lines may respond differently to berberine at certain concentrations.

The anticancer effects of COP and BER may involve other pathways. Both 5-FU and CPT inhibit cellular DNA replication [26,27], and TAX inhibits cell division by stabilizing microtubules, triggering death of rapidly dividing cancerous cells [28]. Some studies [29,30] have indicated that COP and BER exhibit anticancer effects by inhibiting the activity of DNA topoisomerases and protein kinase C. Our previous study [9] showed that COP and BER markedly inhibit cell proliferation and induce apoptotic cell death of MCF-7 cells through up-regulation of interferon- $\beta$, an important cytokine that regulates cell growth and death. COP and BER also enhance the anticancer effect of estrogen receptor antagonists, including tamoxifen and fulvestrant, likely by regulating multiple cancerrelated genes, e.g., EGFR, HER2, bcl-2, COX-2, and $p 21$ [10]. In this study, we observed some differences in efficacy between COP and BER. It may be that there were components in COP other than BER that contributed to its anticancer effect in agreement with our previous studies $[9,10]$. Further studies are required to discover the pathways targeted by COP and BER.

\section{Conclusions}

This study demonstrated that combinations of COP or BER with chemotherapeutic drugs (5-FU, CPT, and TAX) are more effective in inhibiting the growth of A549 cells than that of any single-agent therapy, possibly due to increased production of ROS and reduce MDR.

\section{Abbreviations \\ COP: Coptis extract; BER: Berberine; 5-FU: Fluorouracil; CPT: Camptothecin; TAX: Paclitaxel; NSCLC: Non-small cell lung cancer; ROS: Reactive oxygen species; MDR: Multidrug resistance; DMSO: Dimethyl sulfoxide; DCFH- DA: 2',7'-dichlorofluorescein diacetate; DCF: Dichlorofluorescein; Pgp: P-glycoprotein.}

\section{Competing interests}

The authors declare that they have no competing interests.

\section{Acknowledgements}

We thank Sarah A. Brigandi, Marilla C. Pender-Cudlip, and Erin D. Gleason for assistance in manuscript preparation. This work was partially supported by the NIH grant CA113605 (to JK) and the National Natural Science Foundation of China (30672741 to KZ). We also thank Dr. Qingwen Zhang from the University of Macau for providing Coptis extract.

\section{Author details}

'Department of Medicine, Massachusetts General Hospital and Harvard Medical School, Charlestown, Boston, MA 02129, USA. ² State Key Laboratory of Quality Research in Chinese Medicine, University of Macau, Macao, SAR, China. ${ }^{3}$ Institute of Chinese Medical Sciences, University of Macau, Macao, SAR, China. ${ }^{4}$ Department of Nephrology, The First Affiliated Hospital of Sun Yat-sen University, Guangzhou, Guangdong , China. ${ }^{5}$ Biochemistry and Molecular Biology Institute, Guangdong Medical College, Zhanjiang, Guangdong, China.

\section{Authors' contributions}

JK conceived of the study, designed the study, and wrote the manuscript. $\mathrm{CH}$ designed the study, performed the experiments, analyzed the data and wrote the manuscript. RR performed the experiments and wrote the manuscript. JL performed the experiments, assisted the study design and data analysis. JW performed the experiments. KZ provided the materials and designed the study. All authors read and approved the final manuscript.

Received: 15 July 2011 Accepted: 21 April 2012

Published: 30 April 2012

\section{References}

1. Yin J, Zhang H, Ye J: Traditional Chinese medicine in treatment of metabolic syndrome. Endocr Metab Immune Disord Drug Targets 2008, 8:99-111.

2. Chang YC, Chen LY: Determination of berberine in coptis. Yao Xue Xue Bao 1962, 13:418-423. 
3. Tang J, Feng Y, Tsao S, Wang N, Curtain R, Wang Y: Berberine and Coptidis rhizoma as novel antineoplastic agents: a review of traditional use and biomedical investigations. J Ethnopharmacol 2009, 126:5-17.

4. lizuka N, Miyamoto K, Okita K, Tangoku A, Hayashi H, Yosino S, Abe T, Morioka T, Hazama S, Oka M: Inhibitory effect of Coptidis Rhizoma and berberine on the proliferation of human esophageal cancer cell lines. Cancer Lett 2000, 148:19-25.

5. Tang F, Wang D, Duan C, Huang D, Wu Y, Chen Y, Wang W, Xie C, Meng J, Wang L, Wu B, Liu S, Tian D, Zhu F, He Z, Deng F, Cao Y: Berberine inhibits metastasis of nasopharyngeal carcinoma 5-8 F cells by targeting Rho kinase-mediated Ezrin phosphorylation at threonine. J Biol Chem 2009, 284:27456-27466.

6. Jantova S, Cipak L, Cernakova M, Kost'alova D: Effect of berberine on proliferation, cell cycle and apoptosis in HeLa and L1210 cells. J Pharm Pharmacol 2003, 55:1143-1149.

7. Wang N, Feng Y, Zhu M, Tsang CM, Man K, Tong Y, Tsao SW: Berberine induces autophagic cell death and mitochondrial apoptosis in liver cancer cells: the cellular mechanism. J Cell Biochem 2010, 111:1426-1436.

8. Soule HD, Vazquez J, Long A, Albert S, Brennan M: A human cell line from a pleural effusion derived from a breast carcinoma. J Nat/ Cancer / 1973, 51(5):1409-1416.

9. Kang JX, Liu J, Wang J, He C, Li FP: The extract of huanglian, a medicinal herb, induces cell growth arrest and apoptosis by upregulation of interferon-beta and TNF-alpha in human breast cancer cells. Carcinogenesis 2005, 26:1934-1939.

10. Liu J, He C, Zhou K, Wang J, Kang JX: Coptis extracts enhance the anticancer effect of estrogen receptor antagonists on human breast cancer cells. Biochem Biophys Res Commun 2009, 378:174-178.

11. Delbaldo C, Michiels S, Syz N, Soria JC, Le Chevalier T, Pignon JP: Benefits of adding a drug to a single-agent or a 2-agent chemotherapy regimen in advanced non-small-cell lung cancer: a meta-analysis. J Am Med Assoc 2004, 292:470-484

12. Simon HU, Haj-Yehia A, Levi-Schaffer F: Role of reactive oxygen species (ROS) in apoptosis induction. Apoptosis 2000, 5:415-418.

13. Gallego MA, Ballot C, Kluza J, Hajji N, Martoriati A, Castera L, Cuevas C, Formstecher P, Joseph B, Kroemer G, Bailly C, Marchetti P: Overcoming chemoresistance of non-small cell lung carcinoma through restoration of an AIF-dependent apoptotic pathway. Oncogene 2008, 27:1981-1992.

14. Young LC, Campling BG, Cole SP, Deeley RG, Gerlach JH: Multidrug resistance proteins $M R P 3, M R P 1$, and MRP2 in lung cancer: correlation of protein levels with drug response and messenger RNA levels. Clin Cancer Res 2001, 7:1798-1804.

15. Cancer Collaborative Group: Chemotherapy in non-small cell lung cancer: a meta-analysis using updated data on individual patients from 52 randomised clinical trials. Non-small Cell Lung Brit Med J 1995, 311: 899-909.

16. Giaccone G, Herbst RS, Manegold C, Scagliotti G, Rosell R, Miller V, Natale RB, Schiller JH, Von Pawel J, Pluzanska A, Gatzemeier U, Grous J, Ochs JS, Averbuch SD, Wolf MK, Rennie P, Fandi A, Johnson DH: Gefitinib in combination with gemcitabine and cisplatin in advanced non-small-cell lung cancer: a phase III trial-INTACT 1. J Clin Oncol 2004, 22:777-784.

17. Brown JR, DuBois RN: Cyclooxygenase as a target in lung cancer. Clin Cancer Res 2004, 10:4266s-4269s.

18. Giard DJ, Aaronson SA, Todaro GJ, Arnstein P, Kersey JH, Dosik H, Parks WP: In vitro cultivation of human tumors: Establishment of cell lines derived from a series of solid tumors. J Natl Cancer / 1973, 51(5):1417-1423.

19. Fontaine M, Elmquist WF, Miller DW: Use of rhodamine 123 to examine the functional activity of P-glycoprotein in primary cultured brain microvessel endothelial cell monolayers. Life Sci 1996, 59:1521-1531.

20. Brouty-Boye D, Kolonias D, Wu CJ, Savaraj N, Lampidis TJ: Relationship of multidrug resistance to rhodamine- 123 selectivity between carcinoma and normal epithelial cells: taxol and vinblastine modulate drug efflux. Cancer Res 1995, 55:1633-1638.

21. Burdon $\mathrm{RH}$ : Superoxide and hydrogen peroxide in relation to mammalian cell proliferation. Free Radic Biol Med 1995, 18:775-794.

22. Pelicano H, Carney D, Huang P: ROS stress in cancer cells and therapeutic implications. Drug Resist Updat 2004, 7:97-110.

23. Hur JM, Hyun MS, Lim SY, Lee WY, Kim D: The combination of berberine and irradiation enhances anti-cancer effects via activation of p38 MAPK pathway and ROS generation in human hepatoma cells. J Cell Biochem 2009, 107:955-964
24. Liu B, Wang G, Yang J, Pan X, Yang Z, Zang L: Berberine Inhibits Human Hepatoma Cell Invasion without Cytotoxicity in Healthy Hepatocytes. PLoS One 2011, 6(6):e21416.

25. Benhar M, Engelberg D, Levitzki A: ROS, stress-activated kinases and stress signaling in cancer. EMBO Rep 2002, 3:420-425.

26. Longley DB, Harkin DP, Johnston PG: 5-fluorouracil: mechanisms of action and clinical strategies. Nat Rev Cancer 2003, 3(5):330-338.

27. Wall ME, Wani MC, Cook CE, Palmer KH, McPhail Al, Sim GA: Plant antitumor agents. I. The isolation and structure of camptothecin, a novel alkaloidal leukemia and tumor inhibitor from camptotheca acuminate. J Am Chem Soc 1966, 88(16):3888-3890.

28. Wani M, Taylor H, Wall M, Coggon P, McPhail A: Plant antitumor agents. VI. The isolation and structure of taxol, a novel antileukemic and antitumor agent from Taxus brevifolia. J Am Chem Soc 1971, 93(9):2325-2327.

29. Kim SA, Kwon Y, Kim JH, Muller MT, Chung IK: Induction of topoisomerase II-mediated DNA cleavage by a protoberberine alkaloid, berberrubine. Biochemistry 1998, 37:16316-16324.

30. Lin TH, Kuo HC, Chou FP, Lu FJ: Berberine enhances inhibition of glioma tumor cell migration and invasiveness mediated by arsenic trioxide. BMC Cancer 2008, 8:58.

doi:10.1186/1749-8546-7-11

Cite this article as: He et al:: Effects of Coptis extract combined with chemotherapeutic agents on ROS production, multidrug resistance, and cell growth in A549 human lung cancer cells. Chinese Medicine 2012 7:11.

\section{Submit your next manuscript to BioMed Central and take full advantage of:}

- Convenient online submission

- Thorough peer review

- No space constraints or color figure charges

- Immediate publication on acceptance

- Inclusion in PubMed, CAS, Scopus and Google Scholar

- Research which is freely available for redistribution 